The Common Agricultural Policy of the European Union the present and the future

EU Member States

point of view 



\section{INSTITUTE OF AGRICULTURAL AND FOOD ECONOMICS NATIONAL RESEARCH INSTITUTE}

\section{The Common Agricultural Policy of the European Union - the present and the future}

\section{EU Member States point of view}

Editors:

dr Marek Wigier

prof. dr hab. Andrzej Kowalski

Proceedings of the International Scientific Conference

"The Common Agricultural Policy of the European Union - the present and the future" Multi-Annual Programme 2015-2019

"The Polish and the EU agricultures 2020+. Challenges, chances, threats, proposals" 5-7 December 2017 Stare Jabłonki, Poland

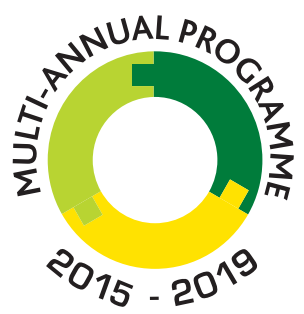

THE POLISH AND THE EU AGRICULTURES 2020+ CHALLENGES, CHANCES, THREATS, PROPOSALS

Warsaw 2018 
This monograph was prepared under the Multi-Annual Programme 2015-2019

"The Polish and the EU agricultures 2020+. Challenges, chances, threats, proposals".

The publication is a collection of selected papers delivered at the 22th edition of the International Scientific Conference organized by the Institute of Agricultural and Food Economics - National Research Institute. The theme of the conference was "The Common Agricultural Policy of the European Union the present and the future. The conference was placed on 5-7 December 2017 in Stary Jabłonki in Poland. Common Agricultural Policy was and still is one of the key pillars of European integration. Published in two volumes materials refer directly to the current and future of the CAP in EU and non EU member states, the strategic objectives and principles of agricultural policy for the agri-food sector and rural areas, address the issues of equilibrium between agriculture, forestry and land use, relate to the dilemmas for the EU budget and the CAP after 2020, CAP instruments and their adjustment, transformations of the rural economy and programming of the rural and agricultural policy, as well as productivity and production efficiency and tensions between sectoral action and between different models of territorial activities.

In the Scientific Committee of the Conference was participated: Prof. Andrzej Kowalski (IAFE-NRI, Poland), Prof. Drago Cvijanonivić (University of Kragujevac, Serbia), Prof. Thomas Doucha (IAEI, Czech Republic), Noureddin Driouech, PhD (CIHEAM, Italy), Prof. Szczepan Figiel (IAFE-NRI, Poland), Prof. Masahiko Gemma (Waseda University, Japan), Prof. Wojciech Józwiak (IAFE-NRI, Poland), Prof. Jacek Kulawik (IAFE-NRI, Poland), Prof. Yuriy Oleksiyovych Lupenko (IAE, Ukraina), Prof. Věra Majerová (CULS, Prague), Prof. Dimitre Nikolov (IAE, Bulgaria), Maire Nurmet, PhD (EMÜ, Estonia), Prof. Gabriel Popescu (ASE, Romania), Norbert Potori, PhD (AKI, Hungary), Prof. Włodzimierz Rembisz (IAFE-NRI, Poland), Piotr Szajner, PhD (IAFE-NRI, Poland), Prof. Alina Sikorska (IAFE-NRI, Poland), Prof. Jonel Subić (IAE, Serbia), Prof. Samuele Trestini (UNIPD, Italy), Prof. Olga Varchenko (Bila Tserkva National Agrarian University, Ukraine), Dipl.-Ing. Klaus Wagner (AWI, Austria), Marek Wigier, PhD (IAFE-NRI, Poland), Prof. Józef St. Zegar (IAFE-NRI, Poland)

In the Organising Committee of the Conference was participated: Małgorzata Bułkowska (IAFE-NRI, Poland), Anna Hankiewicz (IAFE-NRI, Poland), Joanna Jaroszewska (IAFE-NRI, Poland), Joanna Korczak (IAFE-NRI, Poland), Krzysztof Kossakowski (IAFE-NRI, Poland), Irena Mikiewicz (IAFE-NRI, Poland), Małgorzata Mikołajczyk (IAFE-NRI, Poland), Lech Parzuchowski (IAFE-NRI, Poland), Ewa Sierakowska (IAFE-NRI, Poland), Paulina Smakosz (IAFE-NRI, Poland), Leszek Ślipski (IAFE-NRI, Poland), Marek Wigier, PhD (IAFE-NRI, Poland).

Reviewers:

Professor Dimitre Nikolov, Institute of Agricultural Economics, Sofia, Bulgaria

Professor Gabriel Popescu, The Bucharest University of Economic Studies, Bucharest, Romania

Professor Samuele Trestini, University of Padva, Italy

Proofreader

Katarzyna Mikulska

Technical editors:

Joanna Jaroszewska, Barbara Pawtowska, Ewa Sierakowska, Kamila Tomaszewska,

Barbara Walkiewicz

Translated by

Summa Linguae S.A.

Cover Project

Leszek Ślipski

ISBN 978-83-7658-743-1

DOI: $10.30858 / \mathrm{pw} / 9788376587431$

Instytut Ekonomiki Rolnictwa i Gospodarki Żywnościowej

- Państwowy Instytut Badawczy

ul. Świętokrzyska 20, 00-002 Warszawa

tel.: (22) 5054444

faks: (22) 5054636

e-mail:dw@ierigz.waw.pl

http://www.ierigz.waw.pl 


\section{Contents}

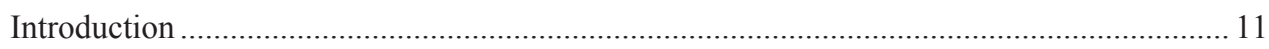

Dr Marek Wigier

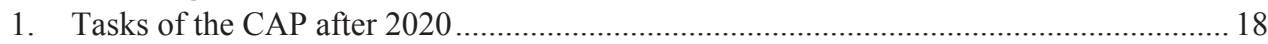

Dr hab. Julian Krzyżanowski

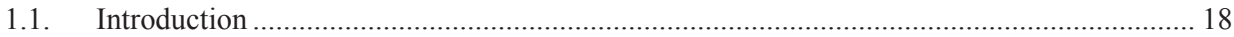

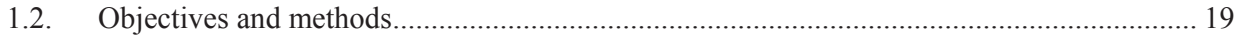

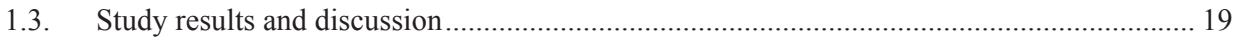

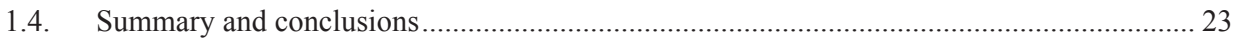

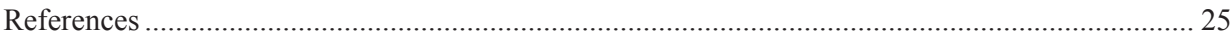

2. An assessment of the regional impacts of post-2020 CAP budgetary cuts on production

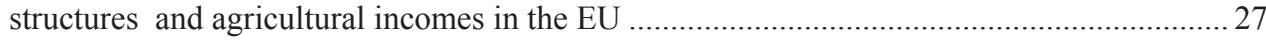

PhD Norbert Potori, PhD János Sávoly, PhD Szabolcs Biró

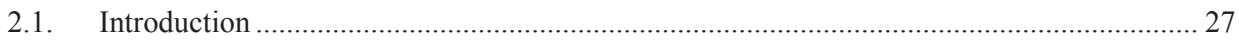

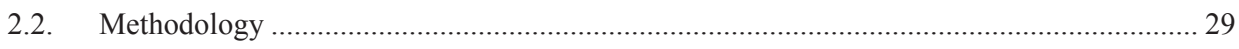

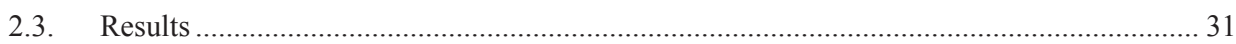

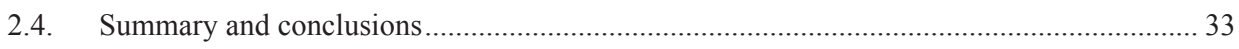

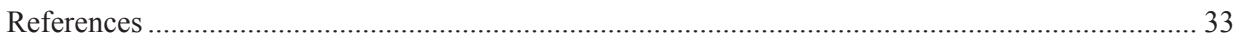

3. Is there room for financial instruments in the Common Agricultural Policy? Casus of

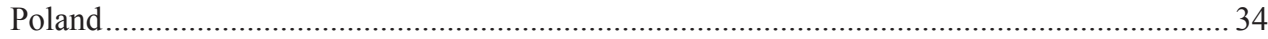

Prof. dr hab. Jacek Kulawik, PhD Barbara Wieliczko, PhD Michat Soliwoda

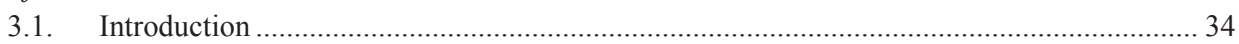

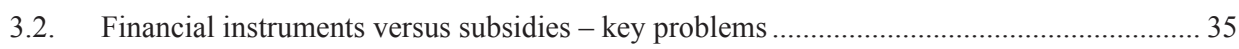

3.3. The use of financial instruments under the EU policy ......................................................... 37

3.4. Example of the use of FI in the 2014-2020 programming period ......................................... 38

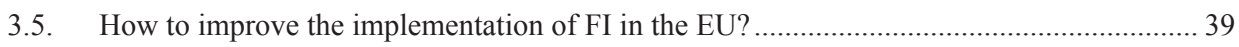

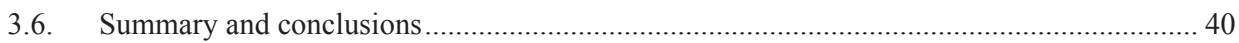

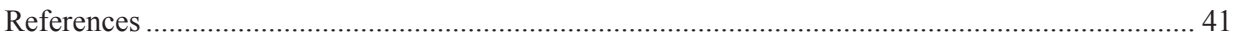

4. The past, present and future of the CAP - the Hungarian viewpoint ............................. 43

Dr Tamás Mizik

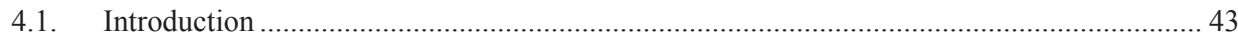

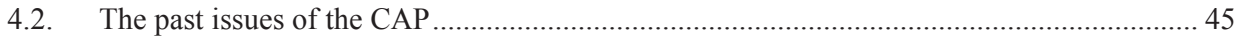

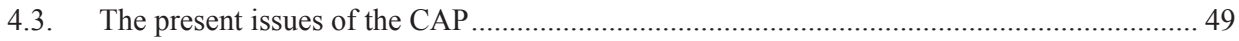

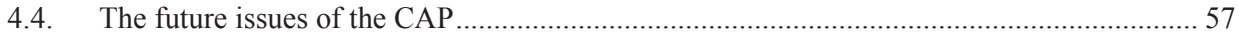

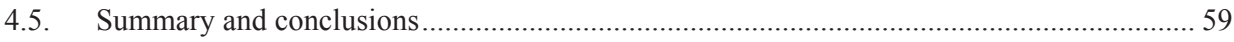

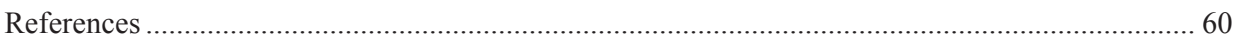


5. Going beyond the Rural Development Programme: a Master Plan for Austria's rural areas in the framework of the CAP

Dip.-Ing. Klaus Wagner

5.1. Introduction

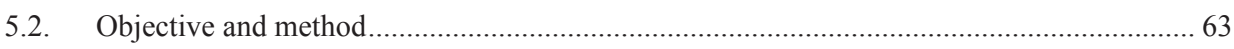

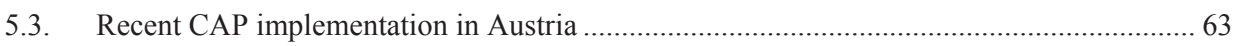

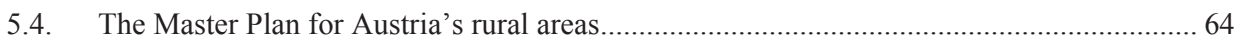

5.5. CAP in the system of the EU policy objectives and in the view of regional science

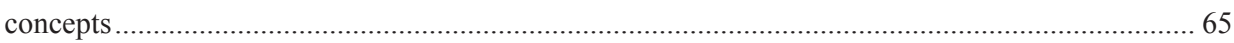

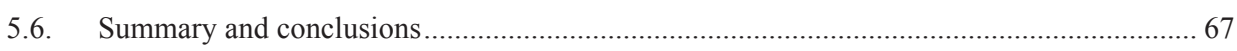

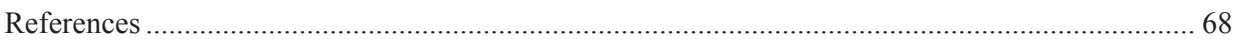

6. Possibilities to connect the Romanian agricultural research to the market requirements 69 Prof. Gabriel Popescu

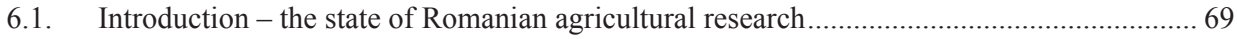

6.2. The problems faced by agricultural research since 1990 ..................................................... 71

6.3. Possible solutions for the recovery of Romanian agricultural research ................................ 76

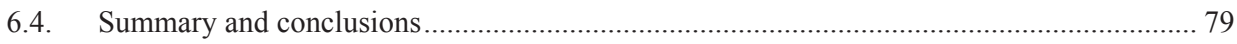

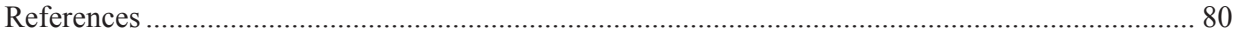

7. Price relationships of the production factors as exogenous determinants of production in agriculture.

Prof. dr hab. Włodzimierz Rembisz, PhD Adam Waszkowski

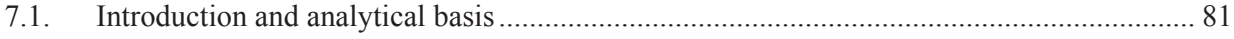

7.2. Relationships of prices of the capital, labour and land factors - hypothetical approach...... 83

7.3. Relationships of prices of the capital, labour and land factors - empirical approach .......... 84

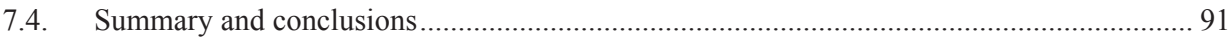

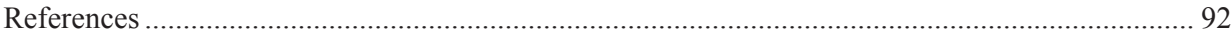

8. Effects of direct payments on agricultural development in Bulgaria ............................. 93 PhD Bozhidar Ivanov

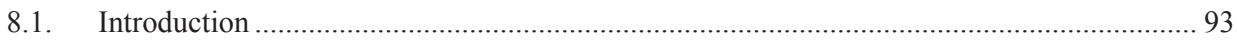

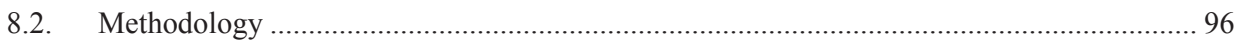

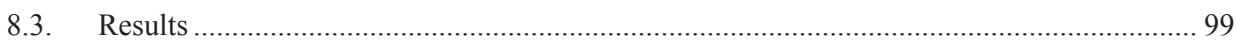

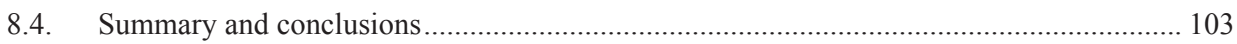

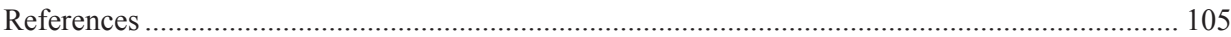

9. Re-adjusting risk management within the CAP: evidences on the implementation of the

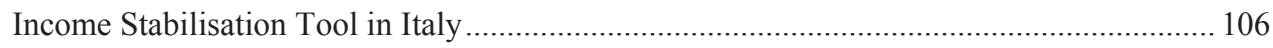
Prof. Samuele Trestini, PhD Elisa Giampietri

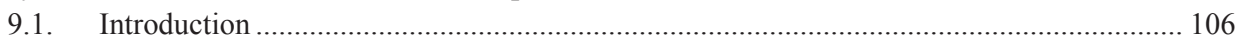

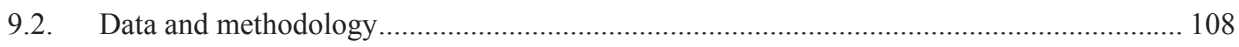




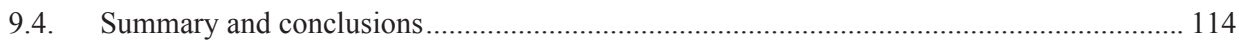

References

10. Comparison of risk management tools under the CAP of the EU, the US Farm Bill

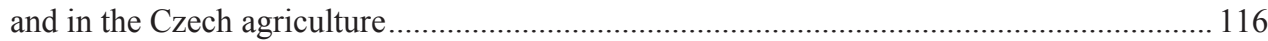
Ing. Václav Vilhelm, CSc., Ing. Sumudu Namali Gouri Boyinová, PhD Jindřich Špička

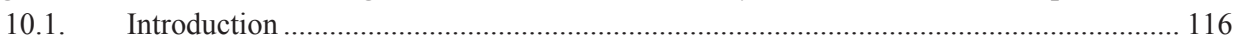

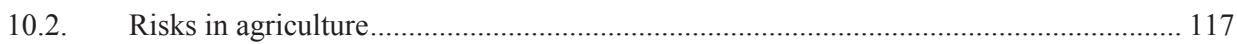

10.3. Risk management policy in the United States Farm Bill 2014 _..................................... 118

10.4. Risk management policy of the European Union's CAP ................................................ 119

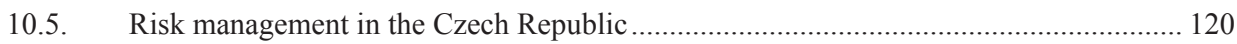

10.6. Comparative analysis of risk management policies ........................................................ 121

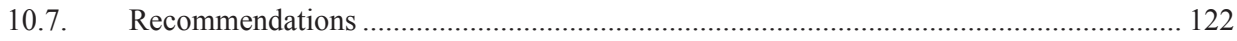

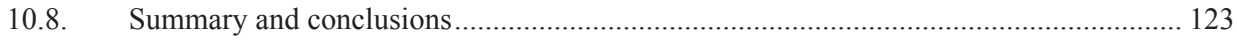

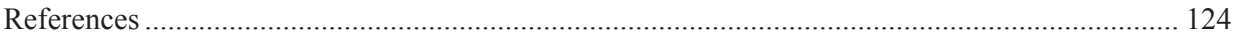

11. Factors determining the crop insurance level in Poland taking into account the level

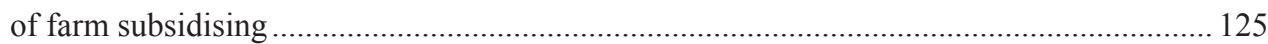

Prof. Adam Was, PhD Pawet Kobus

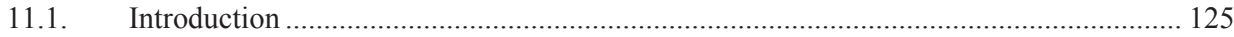

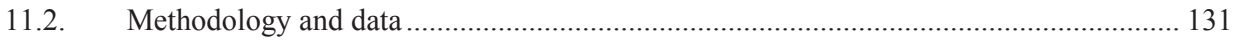

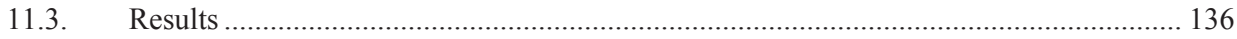

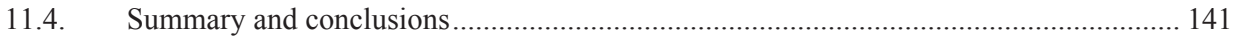

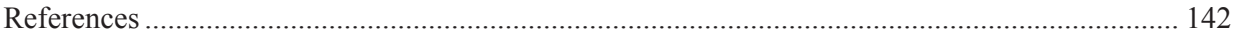

12. Farms and agricultural enterprises for development of sustainable and smart cooperatives: a multifactor approach using digital farm management ............................... 147 Prof. dr habil Adriana Mihnea, Prof. dr Dimitre Nikolov, dr Krasimir Kostenarov

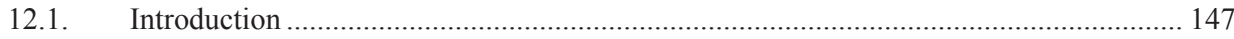

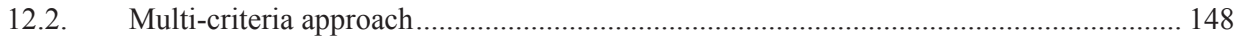

12.3. Construction of Farm Management Model ................................................................ 150

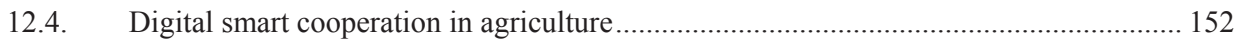

12.5. Application of the ANP Farm Management Model ....................................................... 154

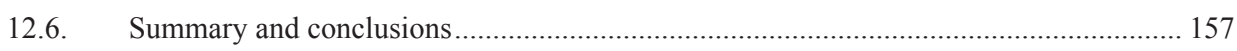

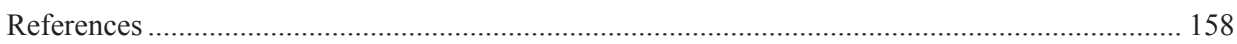

13. Brexit - potential implications for the Polish food sector .............................................. 159

Dr Katarzyna Kosior, Dr Łukasz Ambroziak

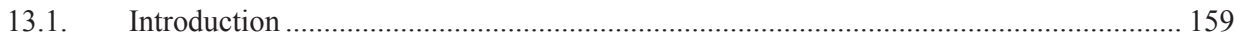

13.2. Negotiations on Brexit - what should be the model of the future relations? ..................... 161

13.3. The future of the EU finances and the CAP in the context of Brexit .............................. 163 
13.4. Impact of possible changes in the CAP budget on the net balance of Poland and transfers to the Polish agriculture.

13.5. The potential impact of Brexit on agri-food trade between Poland and the United

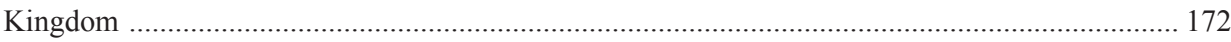

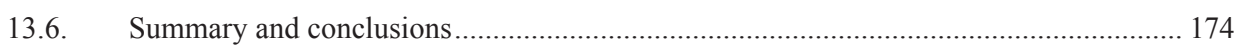

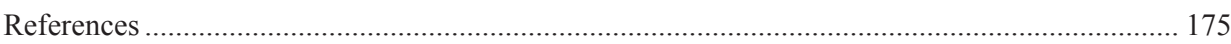

14. The Transatlantic Trade and Investment Partnership (TTIP): a threat or an opportunity for the EU-Mediterranean agriculture and agri-food sector? An exploratory survey ........... 177 Dipl.-Ing. Katja Pietrzyck, PhD Noureddin Driouech, Prof. Brigitte Petersen

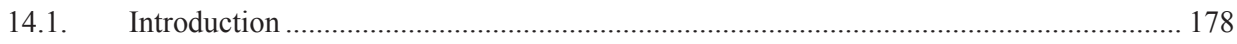

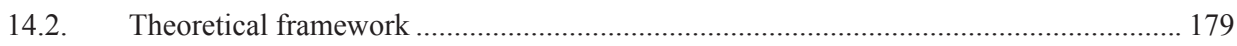

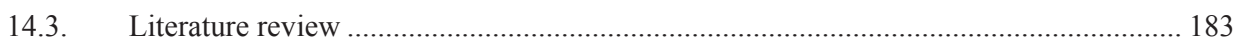

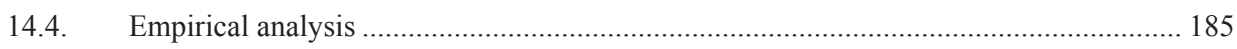

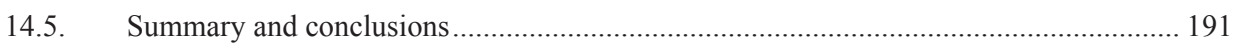

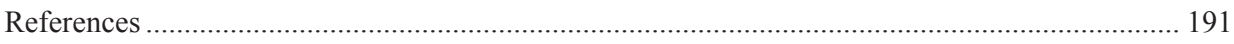

Appendix I: Overview of trade statistics regarding selected products ........................................... 195

15. The concept of short supply chains in the food economy............................................. 196

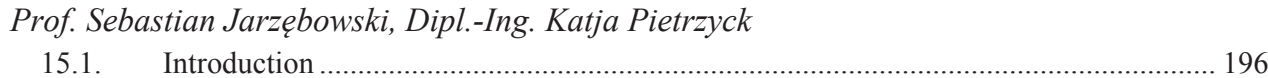

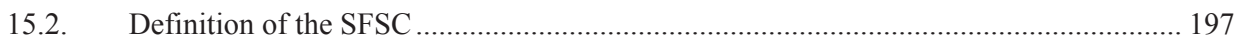

15.3. Development of short supply chains in Europe............................................................. 201

15.4. Global context of European short supply chains ........................................................... 205

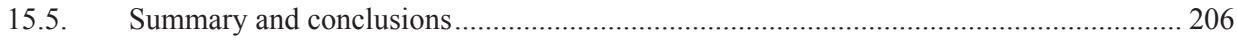

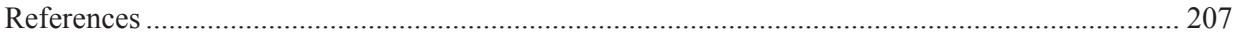

16. The CAP implementation in Wallonia - today performance and questions for the future -

A brief supplementary comment from Warmia and Mazury perspective............................. 209

PhD Philippe Burny, PhD Benon Gazinski

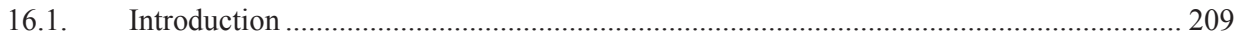

16.2. Implementation of the green payment in Wallonia in 2015 ........................................ 210

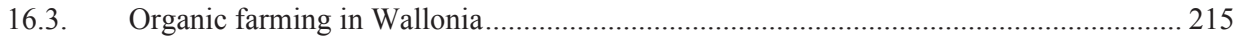

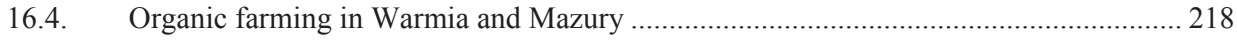

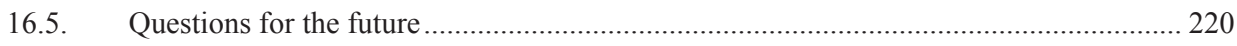

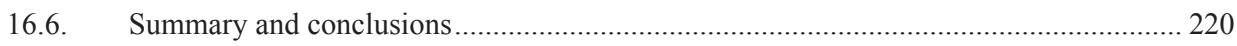

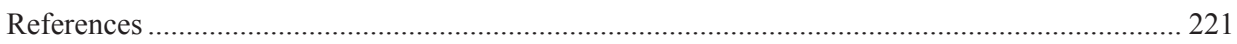

17. Afforestation of agricultural land financed from the RDP 2014-2020 ....................... 224

PhD Marek Zieliński

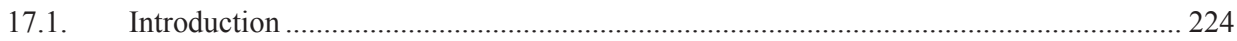

17.2. Natural farming conditions in Poland in regional terms................................................. 225 
17.3. The impact of natural farming conditions in Poland on the economic situation and the possibility of afforestation on farms

17.4. Land afforestation financed from the RDP 2014-2020 in regional terms

17.5. Importance of land afforestations financed under the RDP 2014-2020 in the EU climate policy for 2021-2030.

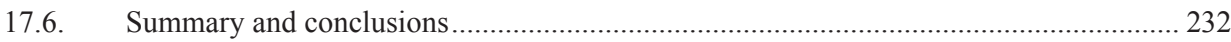

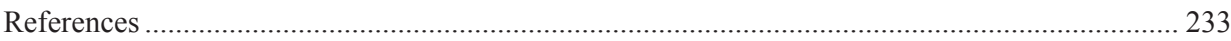

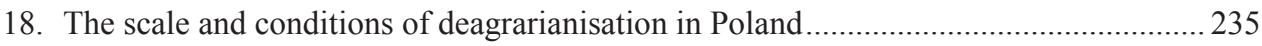

PhD Michat Dudek, PhD Bożena Karwat-Woźniak

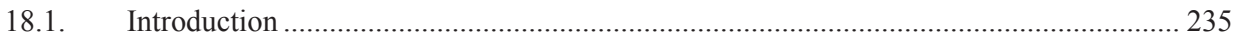

18.2. The conditions of the decrease in employment in agriculture ......................................... 236

18.3. The change in the scale of employment in agriculture in Poland and its conditions....... 238

18.4. The instruments of the Cohesion Policy and agriculture and rural development of the EU

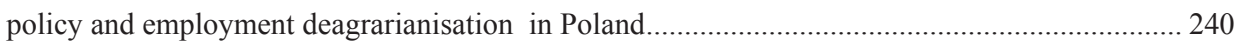

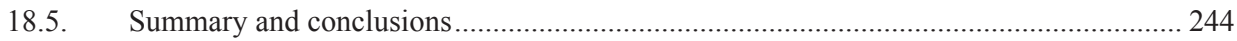

References 245

19. Socio-economic and environmental parameters and results of rural development under the CAP: the case of Bulgaria ................................................................................................ 247 Prof.dr.hab. Julia Doitchinova, Prof.dr.hab. Ivan Kanchev, Ass.Prof. Ralitsa Terziyska PhD, Ass.Prof. Kristina Todorova PhD

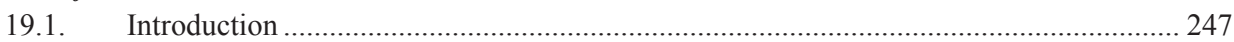

19.2. Changes in Bulgarian rural areas - socio-economic and environmental aspects................ 248

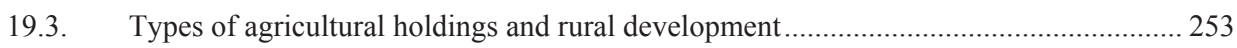

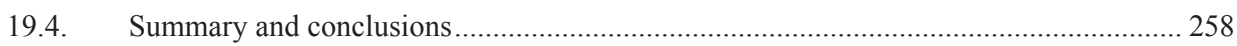

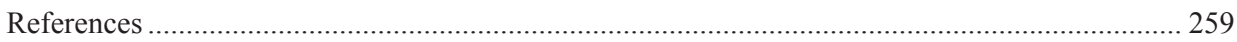

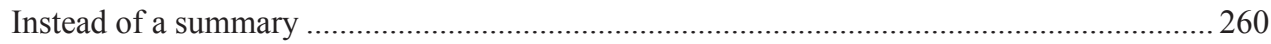

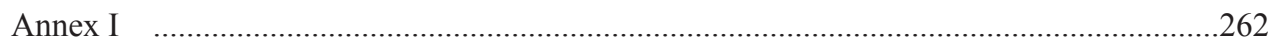




\title{
6. Possibilities to connect the Romanian agricultural research to the market requirements
}

\author{
Prof. Gabriel Popescu, \\ Bucharest University of Economic Studies, Bucharest, Romania, \\ popescug2004@yahoo.co.uk
}

DOI: $10.30858 / \mathrm{pw} / 9788376587431.6$

\begin{abstract}
On the knowledge market, the demand for information and knowledge is determined by a series of factors, of which some have a significant role: the implementation stage of the elements of scientific and technical progress in agriculture; the profile of agricultural producers; the relationship between the cost of information and knowledge, on the one hand, and the prices of agricultural products and, respectively, the ability of farmers to access knowledge in the field of research, on the other hand. The dysfunctions induced in the socio-economic structures after 1990 led to a strong fragmentation and isolation of most agricultural holdings. At the same time, for many management reasons, the agronomic research in Romania, i.e. lost touch with the mass of agricultural producers. Thus, the cooperation that should have occurred between most agricultural holdings and research units not only dwindled to disappearance, but also generated significant losses.

In this context, it is appreciated that the return to the functional parameters of the Romanian research may result from: linking the research, as a priority, to the knowledge market; awareness of the fact that yield increases - per hectare or animal head - will still call for scientific and technical progress; taking the example of foreign, large-scale suppliers of progress factors, which cooperate with farmers in the most diverse forms; studying, assessing and enhancing the vectors of operationalization in the knowledge market, connecting producers and consumers of information; the involvement of information producers, research, the more active dissemination of their results, etc.
\end{abstract}

Keywords: agricultural policy, knowledge market, market requirements, progress factors

JEL codes: O13, Q10, Q14, Q18

\subsection{Introduction - the state of Romanian agricultural research}

Modern Romanian agricultural research began in the years leading up to the First World War. The subsequent development was relatively upward with stagnation and inherent returns generated by system changes to which Romanian society was subjected over time. Nevertheless, in almost a century of existence, 
the most important agricultural and forestry research institution in Romania, namely the Academy of Agricultural and Forestry Sciences "Gheorghe IonescuSisesti" (ASAS), recorded considerable scientific and material accumulations.

Currently, ASAS is a specialized, autonomous public institution of academic consecration and scientific coordination, with legal personality, functioning according to its own statute and it is coordinated by the Ministry of Agriculture and Rural Development and the Ministry of National Education. From the point of view of the institutional architecture of the Romanian agricultural research, we specify that ASAS maintained its configuration specific to the communist period. This phenomenon explains why the dynamics of Romanian agricultural research has entered a declining slope, and there are currently no signs of recovery. The crisis of agricultural research has not been and is not a single fact. The sectoral crisis is manifested in all Romanian research, on the one hand, as a result of immobility of the institutional structures and, on the other, of underfinancing of the sector, which led to both the departure of researchers and the decrease of the number of young people opting for a qualification in the field and to decreasing the results.

In addition, agricultural research has also been the victim of the privatization of agriculture, through de-collectivization and de-privatization, and which, in the field of land relations, have embraced the ęreconstruction and establishment of the property rightę for the lands confiscated by the Communists and / or of the land ownership of state ownership. Because of these actions, a large part of the agricultural research area went into a commercial circuit (at the beginning of the $90 \mathrm{~s}$ the institutes of the ASA had about 130 thousand ha of agricultural land for research, and in 2017 they had 74.6\% less, respectively, about 33 thousand hectares).

In Romania, in the category of producers of information and scientific knowledge for agriculture and forestry there are also the big traditional university centers, such as Bucharest, Iasi, Cluj, Timisoara and Craiova. It is worth mentioning that the universities did not have a scientific production at the level registered by the Academy of Agricultural and Forestry Sciences, because their activities were more of a didactic, educational and editorial nature than research. We appreciate that if the university management were to capitalize with responsibility and efficiency and, at the same time, it would have acted in the direction of enhancing human resources (teachers, researchers, specialists, students), land (agricultural land of any kind) and all the other elements that make up the agricultural capital broadly, it would probably have been significant and useful for agriculture. Notorious, in these cases, were the alienations for the reconstitution of property rights of some lands. In this context, we mention the case of Băneasa Didactic Farm of the University of Agronomic Sciences and Veterinary Medi- 
cine (USAMV) in Bucharest, a unit of over 200 hectares, although under public law, it was transferred privately, being returned to former owners. We do not judge the lawfulness of this action! However, from the point of view of social responsibility in the preparation of the young generation, the decision to renounce the Baneasa Didactic Farm of USAMV in Bucharest has an anti-native character, as it compromises the quality of agriculture specialist of many generations of future engineers, veterinarians or agrarian economists. Such examples can continue because USAMV in Bucharest was not the only institution affected by the laws of the restitution of former land.

\subsection{The problems faced by agricultural research since 1990}

It is widely accepted that investing in research and innovation is driving long-term growth and that the $R \& D$ rate of public funding is estimated to be high. Nevertheless, on the background of the adoption in the Romanian economy of capitalist relations, agricultural research has been confronted with:

- $\quad$ Chronic under-financing of the sector;

- Shortcomings in relations with the market;

- Increasing aggressiveness of competition from foreign companies.

\section{Underfunding of agricultural research}

Undoubtedly, the post-communist Romanian society has drastically reduced the public funds granted to the research, because:

- $\quad$ it constantly faced deep economic and financial imbalances;

- a clear, consistent and predictable doctrinal and legislative line has not been identified, promoted and adopted.

Figure 1. Funds allocated for RDI - overall and for agriculture - in 2008-2016

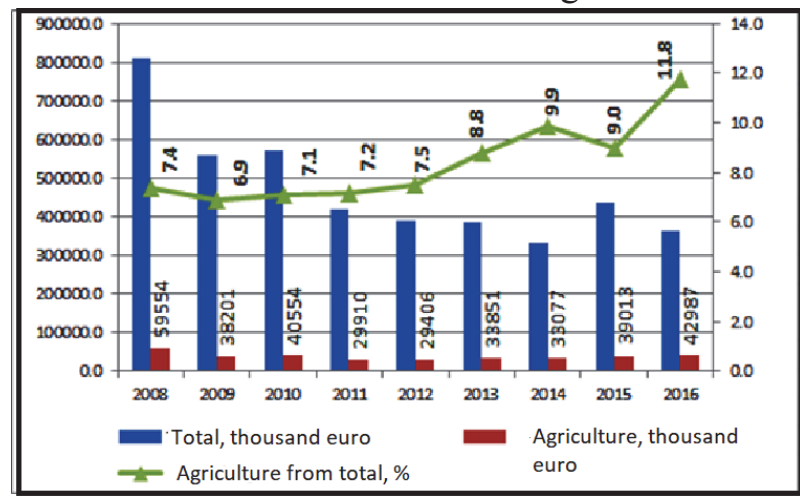

Source: calculations based on (i) Tempo online (accessed on: 10 Nov.2017) and (ii) Annual average exchange rate (arithmetic mean of monthly average exchange rates), NBR website, (accessed on: 10 Nov.2011). 
In 2014, the "National Strategy for Research, Development and Innovation 2014-2020" was launched. This document - legalized by the Government Decision No. 929 of 21 October 2014 - supports the professionalization of the technology transfer segment both from public research institutional structures and from other similar organizations. The National Strategy for Research, Development and Innovation 2014-2020 promotes the intensification of the transfer of technical knowledge, the improvement of intellectual property portfolios, the mobilization of private financial resources towards RDI activities and increased mobility of researchers from public and private organizations. Specifically, the main actions proposed in the document include: (i) financing the thematic projects through a set of instruments; (ii) the possibility of developing short and long-term research on phases of the research cycle (from idea to marketing) with a focus on priority areas; (iii) making research funding in the framework of partner actions between RDI institutes, universities and firms / companies.

\section{Relations with the market}

Agricultural research, from the time of its institutionalization, which took place in the last century, until the moment of the post-totalitarian reforms, has manifested on the market under the form of partnership relations, according to the model described below.

After the collapse of Communism, agriculture was given priority over other sectors of the economy, in an ample and profound process of reform, which had to suffer because of the lack of expertise of the decision-makers.

Also, over a period of about a decade, the network of large agricultural production units, consisting of about 3000 agricultural production cooperatives and nearly 420 state units, has disappeared, and instead small family-type entities have been activated, in the amount of over 4 million, i.e. it is the number registered in 2000.

The latest statistical data from the "Farm Structure Survey, 2016. General National Data" on the small farm household reveals the continued high degree of fragmentation of agricultural economic agents and their degree of participation in agricultural markets. Thus, $93.0 \%$ of the total agricultural holdings have up to 5 hectares, most of them have $2-5$ ha $(19.3 \%$ of the total), followed by households with $1-2$ ha $(18.6 \%)$ and $0.5-1$ ha $(17.0 \%)$. To this reality of the small peasant farms is also added the low degree of participation in the market $7.6 \%$ - which is represented by the number of direct selling households for more than $50 \%$ of the produced output. Only these summary data are likely to reflect the reduced capacity of these entities to gain access to knowledge. 
Table 1. Agricultural holdings by destination of agricultural production, 2016

\begin{tabular}{|c|c|c|c|c|c|c|}
\hline & \multirow[b]{2}{*}{$\begin{array}{c}\text { Agricultural } \\
\text { units } \\
\text { (number) }\end{array}$} & \multicolumn{2}{|c|}{ Of which } & \multirow[b]{2}{*}{$\begin{array}{c}\text { Agricultural } \\
\text { units (\%) }\end{array}$} & \multicolumn{2}{|c|}{ Of which } \\
\hline & & $\begin{array}{c}\text { For own } \\
\text { consumption, } \\
\text { over } 50 \%\end{array}$ & $\begin{array}{c}\text { Direct } \\
\text { sale, over } \\
50 \%\end{array}$ & & $\begin{array}{c}\text { For own } \\
\text { consumption, } \\
\text { over } 50 \%\end{array}$ & $\begin{array}{c}\text { Direct sale, } \\
\text { over } 50 \%\end{array}$ \\
\hline Under 0.1 ha & 421008 & 409342 & 11666 & 12.8 & 13.85 & 3.58 \\
\hline $0.1-0.3$ ha & 540762 & 515226 & 25536 & 16.5 & 17.43 & 7.84 \\
\hline $0.3-0.5$ ha & 287917 & 272081 & 15836 & 8.8 & 9.20 & 4.86 \\
\hline $0.5-1$ ha & 554462 & 519827 & 34635 & 17.0 & 17.58 & 10.64 \\
\hline $1-2$ ha & 611567 & 560145 & 51422 & 18.6 & 18.95 & 15.80 \\
\hline $2-5$ ha & 632950 & 539531 & 93419 & 19.3 & 18.25 & 28.70 \\
\hline $5-10$ ha & 177178 & 123460 & 53718 & 5.4 & 4.18 & 16.50 \\
\hline $10-20$ ha & 36387 & 15157 & 21230 & 1.1 & 0.51 & 6.52 \\
\hline $20-30$ ha & 7166 & 1154 & 6012 & 0.2 & 0.04 & 1.85 \\
\hline $30-50$ ha & 4834 & 353 & 4481 & 0.1 & 0.01 & 1.38 \\
\hline $60-100$ ha & 3378 & 101 & 3277 & 0.1 & 0.00 & 1.01 \\
\hline $\begin{array}{l}100 \text { ha and } \\
\text { over } 100 \text { ha }\end{array}$ & 4286 & 6 & 4280 & 0.1 & 0.00 & 1.31 \\
\hline Total & 3281895 & 2956383 & 325512 & 100 & 100 & 100 \\
\hline
\end{tabular}

* Data refer only to agricultural units without legal personality.

Source: processing after the "Structural Survey in Agriculture, 2016. General Data at National Level” [2017]. Andrei, T. (Coord.), [2017], National Institute of Statistics, Bucharest.

As regards the agricultural research units, even if they managed to go through the reforming process with small changes in their organizational structure, the collapse of the large production units in the agriculture sector meant the beginning of the decline and, later on, of the functional and economic disaster. Nowadays, all the institutes and research centers have been faced with new market relations, which in their essence were based on an unbalanced scheme, incapable of generating functional relationships.

From an economic point of view, such relationships were objectively non-functional because they put in front of over 60 institutes and agricultural and forestry research facilities, the opportunity to economically relate to and interact with almost 4 million small and very small family-type production entities.

Because the economy is frequently imitating or copying models from nature, we could say, without exaggerating and taking into account the physiocrats' opinion, that these relationships were like the cross between a pureblood horse and a donkey, with the mere observation that the product of the two is always sterile. 


\section{Foreign companies' competition}

Romania's integration into the European structures, a process followed almost simultaneously by the liberalization of the markets, has made the results of national agricultural research less and less important to the demand of the domestic producers, when taking into consideration the factors that generate technical progress.

Table 2. Top 15 farmers who applied for APIA subsidies in the 2017 Campaign, selected according to the size of the area requested for payment and presented in ascending order*

\begin{tabular}{|c|c|c|c|}
\hline No. & County & $\begin{array}{l}\text { Agricultural units that have } \\
\text { requsted APIA subsidies in } \\
\text { the } 2017 \text { Campaign }\end{array}$ & Observations \\
\hline 1 & Braila & S.C. AGRICOST S.A & $\begin{array}{l}\text { It has the largest concession area at the State Land } \\
\text { Agency (ADS) of } 57720 \text { hectares. It belongs to busi- } \\
\text { nessman Constantin Duluțe, who took over in } 2012 \\
\text { the contract for land exploitation of the Insula Mare a } \\
\text { Brailei from Culita Tărâță. This company is about to } \\
\text { be bought by the Al Dahra group in the United Arab } \\
\text { Emirates. The transaction will amount more than EUR } \\
200 \text { million** according to www.zf.ro data. }\end{array}$ \\
\hline 2 & Ialomita & S.C. INTERCEREAL S.A. & 18362 ha $* * *$ \\
\hline 3 & Vaslui & S.C. COMCEREAL S.A. & 27488 ha $* * *$ \\
\hline 4 & Timis & $\begin{array}{l}\text { S.C. Emiliana West Rom } \\
\text { S.R.L. }\end{array}$ & $\begin{array}{l}\text { It has in concession or lease an area of } 629 \text { hec- } \\
\text { tares. The firm belongs to the Italian businessman } \\
\text { Luciano Martini. }\end{array}$ \\
\hline 5 & Timis & S.C. CAMPO D ORO S.R.L. & $\begin{array}{l}\text { It operates around } 12000 \text { hectares, being the largest } \\
\text { grain grower in the county. It was set up by Italian } \\
\text { Giovanni Roncato, who later moved into the Danes } \\
\text { portfolio of Ingelby and Emiliana West Rom, con- } \\
\text { trolled by the Italian citizen Luciano Martini. }\end{array}$ \\
\hline 6 & Calarasi & $\begin{array}{l}\text { S.C. MARIA TRADING } \\
\text { S.R.L. }\end{array}$ & $\begin{array}{l}\text { It operates around } 50000 \text { hectares, of which } 11700 \\
\text { ha are concessions from ADS. It is owned by Leba- } \\
\text { nese businessmen Sarkis Sarkis ( } 31.6 \% \text { of shares), } \\
\text { Laoun Youssef ( } 31.6 \% \text { ), El Khalil Jihad (15\%) and } \\
\text { other minority shareholders of Lebanese origin. }\end{array}$ \\
\hline 7 & Dolj & S.C. CERVINA S.A. & $\begin{array}{l}\text { It operates } 9883 \text { hectares (in } 2013 \text { )****. At Cervina } \\
\text { S.A. the majority shareholder is Oltyre SRL }\end{array}$ \\
\hline 8 & Tulcea & $\begin{array}{l}\text { S.C. DELTA-ROM AGRI- } \\
\text { CULTURE S.R.L. }\end{array}$ & $\begin{array}{l}\text { It operates over } 13000 \text { hectares of land in the Dan- } \\
\text { ube Delta concessioned from the Romanian state. It } \\
\text { is owned by the Luxembourg Company Fri-El In- } \\
\text { ternational Holding and SC Cross Wind SRL, } \\
\text { a company of the Danish family farm group Ingle- } \\
\text { by, they do not have land in concession from the } \\
\text { Romanian state. }\end{array}$ \\
\hline 9 & Ialomita & S.C. ZIMBRUL S.A. & $\begin{array}{l}\text { It operates over } 25200 \text { hectares. It is held, accord- } \\
\text { ing to data provided by the site termene.ro, by Nu- } \\
\text { tre Farming SRL, part of the Portuguese Nutre } \\
\text { Group. It entered Romania in } 2005 \text {. }\end{array}$ \\
\hline
\end{tabular}


Table 2. cont.

\begin{tabular}{|c|c|c|c|}
\hline No. & County & $\begin{array}{l}\text { Agricultural units that have } \\
\text { requsted APIA subsidies in } \\
\text { the } 2017 \text { Campaign }\end{array}$ & Observations \\
\hline 10 & Calarsi & S.C. AGROCHIRNOGI S.A. & $\begin{array}{l}\text { It now operates approximately } 24000 \text { hectares. It is } \\
\text { owned, according to the site termene.ro, by Lebanese } \\
\text { citizens El Khalil Raji and Jabre Nassif. }\end{array}$ \\
\hline 11 & Ialomita & $\begin{array}{l}\text { S.C. JD AGRO COCORA } \\
\text { S.R.L. }\end{array}$ & $\begin{array}{l}\text { It has } 9800 \text { ha. It belongs to Romania Farm Invest } \\
\mathrm{A} / \mathrm{S} \text {, a company based in Denmark, owned by a } \\
\text { group of private investors and companies, accord- } \\
\text { ing to the site termene.ro. }\end{array}$ \\
\hline 12 & Teleorman & S.C. AGRINATURA S.R.L. & $\begin{array}{l}9195 \text { ha in operation; the estimated turnover for } \\
2017 \text { is about EUR } 10 \text { million; the main customers } \\
\text { are Cargill, Bunge, Agricover, Titan or Vel Pitar. }\end{array}$ \\
\hline 13 & Dolj & S.C. OLTYRE S.A. & $\begin{array}{l}\text { It operates } 9298 \text { hectares. Serves the businessman } \\
\text { Mihai Anghel****. }\end{array}$ \\
\hline 14 & Tulcea & $\begin{array}{l}\text { S.C. AGRODELTA SIREA- } \\
\text { SA S.A. }\end{array}$ & $\begin{array}{l}\text { In 2014, the Tulcea County Council granted } 9417 \\
\text { hectares of land in the Sireasa area of the Danube } \\
\text { Delta. It belongs to the family of Traian } \\
\text { Rece*****. }\end{array}$ \\
\hline 15 & Vaslui & $\begin{array}{l}\text { S.C. AGROCOMPLEX } \\
\text { BARLAD S.A }\end{array}$ & $\begin{array}{l}\text { It is part of the Racova group, which in } 2016 \text { passed } \\
\text { from the property of Adrian Porumboiu to that of } \\
\text { Trans-OIL Agro-Industrial Group, the largest grain } \\
\text { trader and producer of sunflower oil in the Republic } \\
\text { of Moldova. } \\
\text { He has debts to the State Property Agency amounting } \\
\text { to about RON } 427200 \text { (EUR } 94900 \text { ). } \\
\text { According to the site termene.ro, the company is } \\
\text { now owned by Babylon Overseas, with address in } \\
\text { United Arab Emirates; the lawyer Dimitriu Sorin } \\
\text { Manuel; Duluțe Constantin; Sif II Moldova. }\end{array}$ \\
\hline
\end{tabular}

* The smallest required area (position 1) in ascending order at the highest surface (position 15).

Note: The above selection took into account the fact that the APIA top ranked according to the size of the area requested for payment in the 2017 agricultural campaign, but there may still be areas for which no subsidy was requested and these were not included in the the above ranking of APIA. ** http://www.flux24.ro/cea-mai-mare-firma-de-cereale-din-romania-dorita-de-un-seic/ (accessed on: March 12, 2018). *** The area for which APIA paid subsidies in 2014. **** http://www.gds.ro/Actualitate/201409-02/Cine+sunt+cei+ mai+mari+latifundiari+ai +Olteniei/ (accessed on: March 12, 2018). ***** http://www.economica.net/top-terenuri-agricole-latifundiari-2017-traian-rece-agrodelta-insula-mare-brailadulute-comcereal_138186.html (accessed on: March 12, 2018).

Source: APIA quoted by ECONOMICA.net at: http://www.economica.net/opt-din-15-se-maiexploatatii-agricole-apartin-unor-companies-foreign-un-fond-de- US investment-to-collect-theprinces-subventii_138231.html; http://www.economica.net/exclusiv-latifundiarul-care-ia-subventiide-la-stat-dar-are-datorii-la-agentia-domeniilor-statului_98178.html; https://www.google.com/ url? $q=$ http://www.economica. net / irregularities-in-top-beneficiaries_101003.html \& sa $=U \&$ ved = OahUKEwjHhsClu-HZAhUMxaYKHXqjAfU QFggUMAY\& client = internal-uds-cse \& cx =017785504891785687534: 9ljoqlgmt4g \& usg = AOvVaw2qYuz LYXMBMn821A4FCFlY. 
However, there is an increase in the interest of foreign investors, which is because the Romanian agriculture registered good results every year. It is significant in 2017 when the best result for cereal production in the last decade was noted (Eurostat data shows for Romania, in 2016 as against 2008, an increase in cereal production by $29.3 \%$ while at the EU level a decrease by $5.6 \%$ ). Thus, Romania has become the largest wheat exporter in the EU. Romanian farmers exported not only to the EU Member States but also to non-community customers - 1.2 million tons of wheat, only in July and August 2017. These results are mostly due to the existence of foreign companies, which with advanced technologies, resources and efficient management have contributed to these achievements. For example, the data from APIA in May 2017, for 15 companies that applied for the largest subsidies in the 2017 Campaign, 8 of them (53.3\%) are owned by foreign shareholders.

In fact, the struggle in the market with foreign companies was uneven, losers being constantly domestic actors. Both the research infrastructure and, above all, the decision-makers, usually with indisputable scientific results, have hardly been able to cope with the foreign offensive. I dare to say, previously thought out and planned, based on the most cynical rules of competitive management and marketing, but also based on their long-term experiences.

\subsection{Possible solutions for the recovery of Romanian agricultural research}

The future of recovering the Romanian agricultural research is closely linked to its innovative power. The solution is an action-packed initiative for a Romania dedicated to innovation and research, in this case the field of agriculture and forestry. Thus, Romania will be able to fit into the core requirement of the Europe 2020 strategy, which aims to generate smart, sustainable and inclusive growth.

The key to returning to the functional parameters of Romanian research can result from:

- $\quad$ Connecting research with priority to the market and here we are referring to the knowledge market and, only secondarily, to intensify the efforts to increase budgetary allocations. The latter solution, given the current economic and social context, is not able to offer an optimistic perspective in short and medium term.

- Growing potential of agriculture's demand for progress factors, where research results occupy a central place amid the development of industrial farms at a steady pace.

However, the performance demonstrated by yield increases per hectare or per head of animal requires, first and foremost, technical progress. From 
this point of view, we can say that there is a real demand for the scientific product as a main factor of progress.

- $\quad$ Taking the example of large, foreign companies, which are providers of progress factors.

While these companies intensify contacts with farmers in various forms, through symposiums, seminars, round tables, work visits and others, agricultural research institutes and entities in Romania are becoming more and more insulated. Because of this, the danger of gradual compression up to the disappearance of the national research is not a false alarm, a metaphor, but a reality.

- Studying, evaluating and intensifying the operationalization, on the knowledge market, of the vectors linking producers and consumers of information, namely research and farmers, because:

a) The vectors in question, with special references to education, consultancy, the media and others, do not belong to the producer nor to the consumers of information, which is why they are outside the interests of the two actors.

b) A large part of the mentioned vectors is still under the responsibility of the public authorities, because it has been assumed that the promotion of the novelty at the level of the sector must be in accordance with the national strategic interests and certainly not only in accordance with the particularities of the productive sector.

- Dynamic energies in the knowledge market must come from information producers, as research goes from top to bottom; that is, it goes down from those who generate it to those who need it. Therefore, the first step towards novelty belongs to the researcher, in what concerns both the production and dissemination of the results, and only after that comes the farmer, as an information consumer.

It is a relation that needs support from both sides, but with initiative on the part of the offer. Without the effort of public research, the farmer is either turning to experience, which is much easier yet traditional and poorly productive, or resorting to the market of foreign inputs of technological progress, which are much more expensive than domestic ones and risky in terms of the imposed commercial conditions.

- Accepting the fact that in the knowledge market the highest costs are associated to the information consumers and not to the information producers, respectively, to research. The most often cited example here is the law of gravity. In the time passed since Isaac Newton's formulation of this law, numerous generations of students have so far tried to understand and know it. It is obvious that the efforts related to knowing the law are much 
higher, immeasurably higher than those related to the formulation of the law. By extension, the previous example is also applied in agriculture, although in other fields. For example, much less is spent for the creation of a plant variety or a new animal breed, than for the efforts generated by their assimilation into production.

This phenomenon leads to the conclusion that efforts to support research must be conjugated to those intended to encourage consumption. When only one of the two segments of the market is sustained and encouraged to the detriment of the other, or both are neglected, then, naturally, their activity becomes isolated, according to the pattern of the present situation.

- $\quad$ Bringing research and production closer together by exploiting all the possibilities that can form an efficient bridge between the two components of the knowledge market. The solution promoted by some circles in the sphere of legislative power poles, which understand the reinvigoration of agricultural research through the institutionalization of management as an intermediate structure between research and agricultural producers, does nothing but alienate the producers from the domestic consumers of information. The finality of this proposal, if it becomes a law, can only lead to a double bankruptcy: first of all, the bankruptcy of the newly created structure and secondly, together with it, that of the entire institutional structure that supports current agricultural research.

Obviously, agricultural producers too, especially those connected to high-performance inputs, will experience the shock of such a situation, yet not to an extent that would affect their functionality decisively.

- In the civilized world, the research market is configured into more elaborate schemes that have proven to be functional. Classical information producers, the same as in our case, delegate responsibility for the dissemination of knowledge to territorial centers of rural development. In their turn, agricultural producers are organized into cooperative or associative structures with responsibilities in taking over and disseminating information from territorial centers. This results in a market-based, public and private, functional partnership between medium-sized structures and flexible activities, in which the objectives are compatible.

- $\quad$ Knowledge, as a production factor, will surely and quite soon stop being only abstract and will acquire concrete features once it will be found as an expense element within the cost of all products. Under these circumstances, the center of gravity in research funding will move from the public budget to the private sector, and the responsibility of the research will go mainly to economic agents. 
- Scientific knowledge as a direct product of research has a dual representation in the economy: firstly, it is an intangible asset and secondly, it is a production factor. As intangible asset, it has some essential characteristics, namely: it is the part of the patrimony with the highest dynamics; it has a high degree of volatility when it has the quality of a public good because it escapes the control of the national authority; it has a high speed of movement under the current technical-scientific conditions. The direct consequence of these characteristics is that, under the conditions of the globalization process, knowledge is migrating from countries with poor economies to the developed ones. In other words, scientific knowledge is naturally polarized by the rich world, which facilitates the drain of brains and ideas from countries of origin in terms that exceed the limits of morality or value equivalents.

\subsection{Summary and conclusions}

Retrospectively, and in summary, research, as an agricultural policy issue, has multiple facets that demonstrate the crisis that this sector is going through. It is a profound crisis that lasts for over a quarter of a century!

Contrary to those who wished its disappearance, as was the case of many agriculture-related capacities for producing progress factors such as Tractorul Brașov, the chemical plants, Semănătoarea București and others, the agricultural research miraculosly still exists and still does its duty, even if at odds with what it could normally give.

Here is the merit of all those who have continued their work in the research institutions, as many as they remained after the reform of the economic sector. The fact that these people continued to work in spite of their minimum income and conditions, the system's loss of credibility, the reduction of the public support, and similar things, may have different interpretations that can be motivated by various arguments. Nevertheless, such motivations are rather related to personal factors, than to causes of a general, social, political or even economic nature.

The stubbornness (of the researchers) to continue to work within the research institutions, although in many respects the results of their work bear critical interpretations, has a special value, though. Through them, the flame of the creative power of this nation has survived.

We are now in the period when agricultural research reached the point of maximum supportability from the forces that compressed its space of manifestation. In physics, such a phenomenon determines the implosion of the whole, while in our case, it determines the manifestation of a simple, Hamletian question: "how long it will be able to resist?" 


\section{References}

1. Andrei, T. (Coord.). (2017). Ancheta structurală în agricultură, 2016. Date generale la nivel naţional. Institutul Naţional de Statistică, București.

2. European Commission, Eurostat. Retrieved from: http://ec.europa.eu/ eurostat/documents/203647/771732/Recognised-research-entities.pdf.

3. European Commission, EUROSTAT. Retrieved from: http://ec.europa.eu/ eurostat/web/microdata/overview.

4. Government of Romania, Government Decision no.929/2014 approving the National Strategy for Research, Development and Innovation 2014-2020, published in the Official Monitor, Part I no. 785 of 28.10.2014.

5. http://www.economica.net/opt-din-15-cele-mai-mari-exploatatii-agricole-apartinunor-companii-straine-un-fond-de-investitii-american-va-incasa-cele-mai-marisubventii 138231.html.

6. NIS, Tempo online, accesed on September 10, 2017.

7. Popescu, G. (2017). The role of markets in the development of agricultural research (Manuscript) within "International Conference Competitiveness of Agro-Food and Environmental Economy”, CAFEE 2017, Bucharest, 9-10, November 2017.

8. Popescu, G; Bara, S. (2017). The Knowledge Transfer Economy. Course Notes. (Manuscript), ASE Bucharest. 